\title{
IMPLEMENTASI COMPLIANCE RISK MANAGEMENT SEBAGAI DECISION SUPPORT SYSTEM DALAM KEGIATAN PENAGIHAN DI DIREKTORAT JENDERAL PAJAK
}

\author{
Halida An Nabila ${ }^{1}$ \\ Politeknik Keuangan Negara STAN \\ Primandita Fitriandi², \\ Politeknik Keuangan Negara STAN
}

Alamat Korespondensi: 1401190001_halida@pknstan.ac.id ${ }^{1}$, primandita@pknstan.ac.id²

\section{INFORMASI ARTIKEL}

Diterima Pertama

[19102021]

Dinyatakan Diterima

[02112021]

KATA KUNCI:

Compliance Risk Management, decision support system, prioritas, penagihan pajak, usability

KLASIFIKASI JEL:

$\mathrm{H} 2 \mathrm{O}$

\begin{abstract}
This study aims to analyze the implementation of Compliance Risk Management (CRM) as a decision support system for tax collection purpose at Directorate General of Taxes. This study evaluates the implementation of CRM for tax collection purpose using the usability inquiry to evaluate CRM through questionnaire, observation, and interview. The usability score is obtained from the questionnaire, reflecting the level of usability of CRM as a decision support system in determining priority taxpayers for tax collection action. The validity of the score is then confirmed and deepened by field observations and interviews. Based on the research results, the role of CRM in determining priority for tax collection action is nothing more than a trigger instead of a decision support system it was expected to be. This is due to several shortcomings it poses in terms of effectiveness, efficiency, and accuracy which are mainly caused by slow data update. However, CRM is adequate in terms of understandability, operability, and learnability.
\end{abstract}

\section{ABSTRAK}

Penelitian ini dilakukan untuk menganalisis implementasi dari pemanfaatan Compliance Risk Management (CRM) Fungsi Penagihan sebagai decision support system dalam kegiatan penagihan di Direktorat Jenderal Pajak. Penelitian ini mengevaluasi implementasi CRM Fungsi Penagihan dengan metode usability inquiry yang mengevaluasi CRM dengan kuesioner, observasi, dan wawancara. Dari kuesioner diperoleh skor usability yang mencerminkan tingkat kegunaan dari CRM Fungsi Penagihan sebagai alat pengambilan keputusan dalam penentuan prioritas tindakan penagihan. Validitas skor tersebut dikonfirmasi dan diperdalam dengan observasi lapangan dan wawancara. Berdasarkan hasil penelitian, peran CRM Fungsi Penagihan dalam penentuan prioritas penagihan sejauh ini adalah sebagai trigger, bukan alat pengambilan keputusan utama. Sebab, CRM Fungsi Penagihan masih memiliki banyak kekurangan dalam hal efektivitas, efisiensi, dan akurasi yang utamanya disebabkan oleh pemutakhiran data yang lambat. Namun, CRM Fungsi Penagihan telah memiliki understandability, operability, dan learnability yang cukup memadai. 


\section{PENDAHULUAN}

New Public Management berperan penting dalam meningkatnya kesadaran akan manajemen risiko di organisasi publik (Barrett AO, 2014; Kapuscinska \& Matejun, 2014; Chowdhury \& Shil, 2019). Namun, karena besarnya tekanan pihak eksternal dan tuntutan regulasi di sektor publik, penelitian-penelitian tentang manajemen risiko pada umumnya membahas manajemen risiko sebagai alat akuntabilitas atau alat pengendalian internal (Vincent, 1996; Woods, 2009; Vinnari \& Skaerbaek, 2014; Palermo, 2014; Kapuscinska \& Matejun, 2014; Kong et al., 2018; Carlsson-Wall, 2018). Padahal, selain menjadi alat akuntabilitas dan alat pengendalian internal, manajemen risiko juga berpotensi menjadi alat pengambilan keputusan (Leung \& Isaacs, 2008; Parhizkar et al., 2020). Namun, literatur yang membahas manajemen risiko sebagai alat pengambilan keputusan di sektor publik sulit ditemukan. Untuk itu, penelitian tentang penggunaan manajemen risiko sebagai decision support system (DSS) di sektor publik perlu dilakukan.

Seperti organisasi sektor publik lainnya, otoritas pajak juga menghadapi berbagai risiko dalam menjalankan fungsinya untuk mengumpulkan sumber pendapatan bagi negara. Untuk itulah sejumlah otoritas pajak di berbagai negara mulai memberikan perhatian pada praktik yang dikhususkan untuk mengelola berbagai risiko tersebut (OECD, 2004). Praktik itulah yang dikenal dengan istilah compliance risk management (CRM). Best practices dari implementasi CRM di dunia perpajakan internasional telah menginspirasi Indonesia untuk turut mengadopsi kerangka pengelolaan kepatuhan pajak berbasis manajemen risiko. Pada 11 September 2019, Direktur Jenderal Pajak (Dirjen Pajak) menetapkan Surat Edaran Nomor SE-24/PJ/2019 tentang Implementasi Compliance Risk Management dalam Kegiatan Ekstensifikasi, Pengawasan, Pemeriksaan, dan Penagihan di Direktorat Jenderal Pajak (DJP). CRM diharapkan dapat membantu DJP mencapai tujuan strategis organisasi melalui pemanfaatan alat bantu pengambilan keputusan dalam menjalankan fungsi ekstensifikasi, fungsi pemeriksaan dan pengawasan, serta fungsi penagihan.

CRM terutama diharapkan menjadi gebrakan yang penting untuk mengatasi hambatan dalam kegiatan penagihan yang dilakukan kantor pelayanan pajak karena dianggap dapat membantu Juru Sita Pajak menentukan prioritas objek penagihan secara otomatis. Sebelumnya, Juru Sita harus menyusun prioritas penagihan secara manual berdasarkan ketentuan dalam Surat Edaran Nomor SE-29/PJ/2012 tentang Kebijakan Penagihan Pajak yang kini sudah kurang relevan untuk digunakan. Menurut Laporan Kinerja DJP Tahun 2019, salah satu dampak nyata dari inefisiensi dan ketidakefektifan dalam penetapan prioritas penagihan sebagaimana dipaparkan di atas adalah terjadinya penurunan capaian pencairan piutang pajak nasional dari tahun 2017 s.d. 2019. Di tahun 2017, persentase pencairan piutang pajak mencapai $187,95 \%$ dari target yang ditetapkan. Namun capaian tersebut turun di tahun 2018 menjadi 156,61\% dan turun kembali di tahun 2019 menjadi $126,45 \%$. Selain penurunan kinerja penagihan dalam skala nasional, terdapat pula fenomena unik di tingkat kantor wilayah (kanwil) DJP yang menunjukkan kurang efektifnya tindakan penagihan. Hal ini terjadi di Kanwil DJP Jawa Timur (Jatim) I. Dalam kurun waktu 20172019 Kanwil DJP Jatim I tidak pernah gagal memenuhi target tindakan penagihan. Namun di satu sisi, Kanwil DJP Jatim I masih belum mampu mencapai target pencairan piutang secara optimal. Pada tahun 2017 Kanwil DJP Jatim I mencapai 85,24\% target pencairan piutang. Kemudian pada tahun 2018 capaian tersebut meningkat menjadi 88,64\%. Namun, di tahun 2019 capaian tersebut turun ke angka 64,49\%. Bahkan, di tahun 2019 Kanwil DJP Jatim I termasuk lima belas kantor wilayah dengan capaian persentase pencairan piutang pajak terendah dalam level nasional. Untuk mengatasi masalah ini, kantor-kantor pelayanan pajak di bawah Kanwil DJP Jatim I perlu memprioritaskan tindakan penagihan yang dilakukan agar pencairan piutang yang diperoleh dapat mencapai hasil yang maksimal. Dalam hal ini, CRM Fungsi Penagihan memiliki potensi untuk menjadi alat bantu yang efektif bagi Juru Sita dalam pengambilan keputusan, yaitu untuk menghasilkan prioritas penagihan yang lebih efektif, efisien, dan berkualitas.

Sehubungan dengan terbatasnya literatur manajemen risiko sebagai alat pengambilan keputusan di sektor publik dan adanya fenomena unik di Kanwil DJP Jatim I sebagaimana dipaparkan di atas, studi ini membahas bagaimana CRM Fungsi Penagihan diterapkan sebagai alat pengambilan keputusan bagi Juru Sita Pajak di Kanwil DJP Jatim I dalam memprioritaskan tindakan penagihan. Selain itu, studi ini juga mengevaluasi CRM Fungsi Penagihan sebagai decision support system berdasarkan model usability inquiry untuk mendapatkan skor usability dari CRM dan menilai efektivitas CRM dalam proses pengambilan keputusan penagihan.

\section{KERANGKA TEORI}

\subsection{Compliance Risk Management}

Tujuan utama otoritas pajak adalah menciptakan tingkat kepatuhan pajak setinggi mungkin untuk memastikan penerimaan yang dikumpulkan mencapai jumlah yang maksimal (Highfield, 2013). Namun, otoritas pajak memiliki sumber daya yang terbatas dalam menjalankan fungsinya. Maka, otoritas pajak dituntut untuk melakukan alokasi sumber daya secara rasional dan efisien. Oleh karena itu, dibutuhkan suatu proses yang terstruktur dan sistematis yang dapat membantu otoritas pajak menentukan prioritas dalam melakukan tindakan untuk menegakkan kepatuhan (OECD, 2004). Committee on Fiscal Affairs (Komite Urusan Fiskal) melaporkan dalam Note yang diterbitkan pada Juli 1997 bahwa dalam rangka menjalankan proses tersebut, sejumlah otoritas pajak nasional telah mulai menerapkan prinsip-prinsip 
manajemen risiko (OECD, 2004). Proses tersebut dapat menentukan hal-hal yang diperlukan dalam konteks penegakan kepatuhan dan bagaimana risikorisiko kepatuhan harus diatasi. Proses tersebut dikenal sebagai compliance risk management (CRM) atau manajemen risiko kepatuhan.

Menurut OECD (2004), CRM adalah proses terstruktur dalam rangka identifikasi, penilaian, pemeringkatan, dan penanganan risiko kepatuhan pajak yang dilakukan secara berulang sebagaimana manajemen risiko pada umumnya untuk mendukung pengambilan keputusan dalam konteks penegakan kepatuhan. Sementara itu, menurut EC (2010), CRM adalah proses sistematis yang dilakukan badan administrasi pajak dalam memilih instrumen penanganan untuk menegakkan kepatuhan berdasarkan pengetahuan tentang perilaku Wajib Pajak sesuai dengan kapasitasnya. Maka dapat disimpulkan bahwa CRM adalah serangkaian proses terstruktur dan sistematis yang didasarkan pada prinsip manajemen risiko yang diterapkan otoritas pajak sebagai alat pengambilan keputusan untuk menentukan tindakan yang diperlukan dalam meningkatkan kepatuhan Wajib Pajak.

\subsection{Compliance Risk Management sebagai Decision Support System}

DSS adalah suatu sistem informasi terkomputerisasi yang mendukung aktivitas-aktivitas pengambilan keputusan (Peignot et al., 2012). Dua hal esensial yang membedakan DSS dari sistem terkomputerisasi lainnya adalah fokus pada pengambilan keputusan dan model penggunaan yang interaktif yang mengharuskan baik sistem maupun pengambil keputusan berkontribusi pada pengambilan keputusan (Pick \& Weatherholt, 2013). Pengambilan keputusan merupakan fitur yang penting dari proses manajemen, terutama dengan meningkatnya jumlah informasi yang ada saat ini (Peculea \& Chitescu, 2015). Bahkan, ahli teori klasik manajemen menganggap bahwa pengambilan keputusan memiliki pengertian yang sama dengan manajemen (Drucker, 1956; Simon, 1977). Maka dapat disimpulkan bahwa DSS merupakan salah satu alat dalam manajemen yang digunakan untuk pencapaian tujuan organisasi.

Dalam konteks otoritas pajak, tujuan yang ingin dicapai adalah meningkatkan kepatuhan pajak untuk mengumpulkan penerimaan secara maksimal (Highfield, 2013; OECD, 2004; EC, 2010). Untuk mencapai tujuan tersebut, otoritas pajak harus menghadapi berbagai macam risiko seperti keterbatasan sumber daya, ketidaksempurnaan peraturan, serta kompleksitas lanskap kepatuhan (Chooi, 2020). Karena tuntutan akuntabilitas dan ketatnya pengawasan masyarakat pada sektor publik, otoritas pajak diharuskan untuk mengelola risikorisiko tersebut dengan baik melalui suatu mekanisme manajemen risiko (Vincent, 1996). Maka, selain dipandang sebagai alat akuntabilitas atau pengendalian internal, CRM yang secara khusus didesain bagi otoritas pajak untuk mengelola risiko- risiko kepatuhan dalam rangka mencapai tujuannya juga dapat dilihat sebagai suatu alat bantu pengambilan keputusan. Simpulan tersebut sejalan dengan temuan Leung \& Isaacs (2008) bahwa penggunaan manajemen risiko sebagai alat pengambilan keputusan semakin meningkat di sektor publik.

\section{METODE PENELITIAN}

\subsection{Jenis Penelitian}

Penelitian ini dilakukan dengan metode kombinasi yang dilakukan melalui penggabungan teknik pengumpulan data dan analisis kualitatif dan kuantitatif. Metode kualitatif digunakan dalam penelitian ini untuk mengeksplorasi bagaimana implementasi CRM sebagai DSS dalam kegiatan penagihan. Selain itu metode kualitatif juga akan digunakan untuk mengalisis hasil evaluasi atas kegunaan CRM sebagai DSS dalam kegiatan penagihan. Dalam penelitian ini metode kuantitatif akan digunakan untuk melakukan evaluasi kuantitatifdeskriptif dari CRM. Metode kuantitatif digunakan untuk mengukur seberapa tinggi skor usability dari CRM sebagai DSS dalam kegiatan penagihan di DJP. Data terkait skor usability tersebut diperoleh melalui kuesioner yang dibagikan kepada para responden untuk mengevaluasi CRM berdasarkan aspek efektivitas, efisiensi, akurasi, understandability, operability, dan learnability yang dituangkan dalam skala likert.

Dengan kombinasi kedua metode sebagaimana dijelaskan di atas, data yang akan diperoleh dari penelitian akan lebih valid karena data yang kebenarannya tidak dapat divalidasi dengan metode kuantitatif akan divalidasi dengan metode kualitatif atau sebaliknya (Sugiyono, 2018). Tipe dari metode kombinasi yang digunakan dalam penelitian ini adalah concurrent triangulation model atau model triangulasi campuran. Tipe ini menggunakan metode kuantitatif dan kualitatif secara bersama-sama baik dalam pengumpulan data maupun analisis. Data kualitatif dianalisis secara kualitatif, sedangkan data kuantitatif akan dianalisis dengan statistik. Kemudian, data kuantitatif dan kualitatif tersebut dapat dikelompokkan, dibedakan, dan dicari hubungannya satu sama lain sehingga dapat diambil simpulan apakah kedua data saling memperkuat, memperlemah, atau bertentangan.

\subsection{Analisis Data}

Informasi yang diperoleh dari dokumentasi maupun wawancara kepada Juru Sita Pajak, Kepala Seksi P3, dan Kepala Seksi Bimbingan Penagihan tentang implementasi dari CRM Fungsi Penagihan di Kanwil DJP Jatim I dikondensasi dan diambil simpulannya. Simpulan tersebut diverifikasi secara berulang kepada informan lain saat wawancara dilakukan dan didukung dengan temuan yang diperoleh penulis pada saat melakukan observasi langsung di KPP Pratama Surabaya Wonocolo.

Selanjutnya evaluasi atas CRM Fungsi Penagihan sebagai alat pengambilan keputusan dilakukan. Hasil dari kuesioner yang dibagikan kepada Juru Sita Pajak 
dianalisis berdasarkan teknik analisis data kuantitatif dengan merit system menurut Chiew \& Salim (2003) untuk didapatkan nilai dari setiap aspek usability yang terdiri atas efektivitas, efisiensi, akurasi, keterpahaman, learnability, dan operability. Dalam metode inquiry, beberapa pertanyaan yang relevan dengan tiap-tiap aspek tersebut diajukan kepada para responden. Skor yang diberikan untuk setiap pertanyaan kuesioner berkisar dari 1 sampai dengan 5 dan diinterpretasikan dalam bobot bernilai 0,00 sampai dengan 1,00 (Tabel 1). Bobot dari semua pertanyaan kemudian dijumlah dan dibagi jumlah pertanyaan dalam suatu faktor untuk mendapatkan merit rata-rata setiap faktor yang kemudian dapat diinterpretasikan dengan acuan dalam Tabel 2. Nilai usability dari CRM Fungsi Penagihan yang dikalkulasi berdasarkan merit system dikonfirmasi ulang dengan dokumentasi, wawancara, dan observasi langsung di KPP Pratama Surabaya Wonocolo untuk memperoleh hasil evaluasi yang lebih komprehensif dan andal atas usability atau kegunaan dari CRM Fungsi Penagihan,

Tabel 1 Interpretasi Skala Likert

\begin{tabular}{|c|c|c|c|c|c|}
\hline Opsi & $\begin{array}{c}\text { Sangat } \\
\text { Tidak } \\
\text { Setuju }\end{array}$ & $\begin{array}{c}\text { Tidak } \\
\text { Setuju }\end{array}$ & Ragu-Ragu & Setuju & $\begin{array}{c}\text { Sangat } \\
\text { Setuju }\end{array}$ \\
\hline Skala Likert & 1 & 2 & 3 & 4 & 5 \\
\hline Merit & 0,00 & 0,25 & 0,50 & 0,75 & 1,00 \\
\hline
\end{tabular}

Sumber: Shafinah et al. (2010)

Tabel 2 Interpretasi Merit Menurut Chiew \& Salim (2003)

\begin{tabular}{|c|c|}
\hline Merit Rata-Rata & Tingkat Kegunaan (Usability) \\
\hline $0,00<=A<=0,20$ & Buruk \\
\hline $0,20<A<=0,40$ & Lemah \\
\hline $0,40<A<=0,60$ & Sedang \\
\hline $0,60<A<=0,80$ & Baik \\
\hline $0,80<A<=1,00$ & Sangat Baik \\
\hline
\end{tabular}

Sumber: Shafinah et al. (2010)

\section{HASIL PENELITIAN}

4.1 Implementasi CRM sebagai DSS dalam Melaksanakan Kegiatan Penagihan di Kanwil DJP Jatim I

\subsubsection{Konsep CRM Fungsi Penagihan}

CRM Fungsi Penagihan merupakan risk engine yang memetakan risiko kepatuhan Wajib Pajak dari sisi penagihan. Risiko penagihan adalah hilangnya penerimaan pajak akibat tidak terpenuhinya kewajiban pembayaran atas piutang pajak yang dapat diakibatkan antara lain karena hilangnya kesempatan untuk menagih dan/atau mencairkan piutang pajak. Peta risiko penagihan memetakan seluruh Wajib Pajak yang memiliki tunggakan pajak berdasarkan dua kriteria yaitu kriteria dampak fiskal dan kecenderungan Wajib Pajak untuk membayar. Kriteria dampak fiskal yang direpresentasikan dengan sumbu $Y$ dalam peta risiko merupakan konsekuensi tidak terpenuhinya kewajiban pembayaran piutang pajak. Secara sederhana, sumbu Y mewakili nominal dari tunggakan pajak. Sementara itu, kecenderungan Wajib Pajak untuk membayar yang direpresentasikan dengan sumbu $X$ dalam peta risiko merupakan tingkat kemungkinan ketertagihan piutang berdasarkan keberadaan dan kemampuan Wajib Pajak dan/atau Penanggung Pajak memenuhi kewajiban pembayaran piutang pajak, serta kondisi piutang. Berdasarkan dua kriteria tersebut, CRM menyediakan skor atau nilai risiko untuk tiap-tiap penunggak pajak dan menempatkan mereka pada salah satu dari sembilan kuadran yang memiliki kode warna yang terdiri atas kuadran X1Y1, X1Y2, X1Y3, X2Y1, X2Y2, X2Y3, X3Y1, X3Y2, dan X3Y3. Gambar 1 menunjukkan peta risiko yang dihasilkan oleh CRM Fungsi Penagihan yang didasarkan pada dua kriteria yang telah dijelaskan di atas.

\section{Gambar 1 Peta Risiko CRM Fungsi Penagihan}

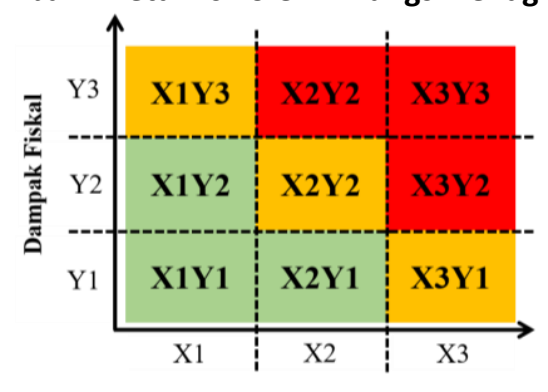

Kecenderungan WP untuk Membayar 
Terdapat dua jenis peta risiko dalam CRM, yaitu peta risiko yang menghasilkan Prioritas Pencairan dan Prioritas Tindakan. Peta risiko Prioritas Pencairan memetakan risiko Wajib Pajak yang sisa umur tunggakannya melebihi 12 bulan. Bentuk peta risiko Prioritas Pencairan dapat dilihat dalam Gambar 1. Wajib Pajak prioritas tinggi menurut peta tersebut adalah yang berada dalam kuadran berwarna merah, meliputi-secara berturut-turut dari yang paling tinggi prioritasnya-kuadran X3Y3, X2Y3, dan X3Y2. Wajib Pajak dalam kuadran tersebut menjadi prioritas utama tindakan penagihan karena selain memiliki dampak fiskal atau nominal tunggakan yang tinggi, Wajib Pajak tersebut juga memiliki kecenderungan membayar yang tinggi. Sementara itu, Wajib Pajak prioritas sedang adalah Wajib Pajak dalam kuadran berwarna kuning yang meliputi-secara berturut-turut dari yang paling tinggi prioritasnya-kuadran X3Y1, X2Y2, dan X1Y3. Wajib Pajak prioritas rendah adalah Wajib Pajak yang dipetakan dalam kuadran berwarna hijau. Wajib Pajak prioritas rendah meliputi-secara berturut-turut dari yang paling tinggi prioritasnya-kuadran X2Y1, X1Y2, dan X1Y1. Wajib Pajak prioritas rendah menjadi prioritas tindakan yang paling akhir karena memiliki dampak fiskal dan kecenderungan membayar yang paling rendah dibandingkan Wajib Pajak dalam kuadran lainnya.

Peta risiko jenis kedua adalah peta risiko Prioritas Tindakan. Bentuk peta risiko jenis ini berbeda dengan jenis sebelumnya. Peta risiko Prioritas Tindakan memetakan Wajib Pajak yang tunggakan pajaknya memiliki sisa umur kurang dari atau sama dengan 12 bulan. Peta risiko ini berbeda dengan peta risiko Prioritas Pencairan karena Juru Sita Pajak harus sesegera mungkin melakukan tindakan penagihan atas tunggakan yang mendekati daluwarsa penagihan. Gambar 2 menyajikan bentuk dari peta risiko Prioritas Tindakan.

\section{Gambar 2 Peta Risiko Prioritas Tindakan CRM Fungsi Penagihan}

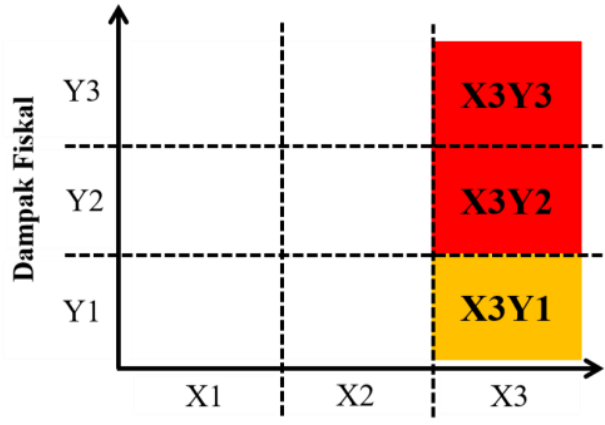

Kecenderungan WP untuk Membayar

Sumber: Diolah Penulis dari Bahan Tayang Bimbingan Teknis CRM

\subsubsection{Proses Bisnis Penentuan Prioritas Sebelum Adanya CRM}

Sebelum diterbitkannya Surat Edaran Dirjen Pajak Nomor SE-24/PJ/2019 tentang Implementasi Compliance Risk Management dalam Kegiatan Ekstensifikasi, Pengawasan, Pemeriksaan, dan Penagihan di DJP, ketentuan tentang kebijakan penagihan mengacu pada Surat Edaran Dirjen Pajak Nomor SE-29/PJ/2012 tentang Kebijakan Penagihan Pajak. Berdasarkan peraturan tersebut, sebagai bagian dari strategi tindakan penagihan, KPP perlu menyusun Kertas Kerja Penagihan (KKP) sebagai dokumentasi atas perencanaan dan pelaksanaan kegiatan penagihan pajak agar tindakan penagihan efektif dan mudah diawasi. KKP tersebut terdiri atas beberapa dokumen, antara lain:

1) Kertas Kerja Analisis Risiko Ketidaktertagihan Piutang Pajak (KKARKPP);

2) Daftar Prioritas Tindakan Penagihan Pajak (DPTPP);

3) Prognosis Pencairan Piutang Pajak;

4) Rencana Kegiatan Penagihan;

5) Laporan Realisasi Prognosis Pencairan Piutang Pajak; dan

6) Kertas Kerja Monitoring Piutang Pajak yang akan Daluwarsa.
Dari keenam dokumen tersebut, dokumen yang merupakan alat bantu dalam menetapkan prioritas tindakan penagihan pajak adalah KKARKPP dan DPTPP. DPTPP yang berisi daftar nama Wajib Pajak prioritas tindakan penagihan dihasilkan setelah KPP melakukan analisis risiko ketidaktertagihan yang dituangkan dalam KKARKPP. Untuk menyusun KKARKPP, KPP harus terlebih dahulu menyusun profil Wajib Pajak. Langkahlangkah yang harus dilakukan untuk menyusun profil Wajib Pajak (profiling) antara lain adalah:

1) mendokumentasikan tindakan penagihan yang sudah dilakukan, seperti mengambil gambar saat memberitahukan Surat Paksa atau melakukan penyitaan;

2) mengonfirmasi kebenaran data aset Wajib Pajak atau Penanggung Pajak;

3) mengumpulkan informasi mengenai Wajib Pajak atau Penanggung Pajak dari media cetak/daring/sosial atau media lainnya dan mendokumentasikannya;

4) berkoordinasi dengan seksi lain di KPP, misalnya dengan Seksi Pemeriksaan untuk mengetahui riwayat pemeriksaan Wajib Pajak; serta

5) mengumpulkan data dan informasi dari pihak ketiga seperti data kepemilikan aset tanah 
dan/atau bangunan atas nama Wajib Pajak/Penanggung Pajak dari Badan Pertanahan Nasional, data pengurus perusahaan dari Kementerian Hukum dan Hak Asasi Manusia, dan sebagainya.

Setelah membuat profil Wajib Pajak, KPP perlu membuat analisis risiko ketidaktertagihan piutang pajak yang didasarkan atas tiga parameter utama yaitu karakteristik piutang, tingkat ketertagihan (tendency to pay), dan kemampuan bayar Wajib Pajak. Risiko ketidaktertagihan dibagi ke dalam tiga kategori, yaitu risiko rendah, risiko sedang, dan risiko tinggi. Skor risiko tiap-tiap Wajib Pajak diberikan dengan acuan sebagaimana disajikan dalam Tabel 3.

Tabel 3 Matriks Risiko Ketidaktertagihan berdasarkan SE-29/PJ/2012

\begin{tabular}{|c|c|c|c|c|c|}
\hline Parameter & $\begin{array}{c}\text { Bobot } \\
(\%)\end{array}$ & $\begin{array}{c}\text { Risiko } \\
\text { Rendah }\end{array}$ & $\begin{array}{l}\text { Risiko } \\
\text { Sedang }\end{array}$ & $\begin{array}{l}\text { Risiko } \\
\text { Tinggi }\end{array}$ & $\begin{array}{c}\text { Jumlah } \\
\text { Skor }\end{array}$ \\
\hline Karakteristik Piutang & 30 & 30 & 15 & 3 & \\
\hline -Umur Piutang & 30 & 9 & 4,5 & 0,9 & $\ldots$ \\
\hline -Peringkat Nilai Piutang WP di KPP & 30 & 9 & 4,5 & 0,9 & $\ldots$ \\
\hline -Kualitas Piutang & 40 & 12 & 6 & 1,2 & $\ldots$ \\
\hline Tingkat Ketertagihan & 30 & 30 & 15 & 3 & \\
\hline -Riwayat Pelaporan & 20 & 6 & 3 & 0,6 & $\ldots$ \\
\hline -Riwayat Pembayaran & 20 & 6 & 3 & 0,6 & $\ldots$ \\
\hline -Riwayat Pemeriksaan & 15 & 4,5 & 2,25 & 0,45 & $\ldots$ \\
\hline -Kondisi Usaha WP & 25 & 7,5 & 3,75 & 0,75 & $\ldots$ \\
\hline -Status/Kondisi Penanggung Pajak & 20 & 6 & 3 & 0,6 & $\ldots$ \\
\hline Kemampuan Membayar & 40 & 40 & 20 & 4 & \\
\hline -Keberadaan dan nilai aset WP & 50 & 20 & 10 & 2 & $\ldots$ \\
\hline -Keberadaan dan nilai aset Penanggung Pajak & 50 & 20 & 10 & 2 & $\ldots$ \\
\hline \multicolumn{5}{|c|}{ Total Skor } & \\
\hline
\end{tabular}

Sumber: Lampiran SE-29/PJ/2012

Berdasarkan Tabel 3, parameter pertama yang dijadikan pertimbangan dalam menentukan prioritas tindakan penagihan adalah karakteristik dari piutang. Karakteristik piutang meliputi umur piutang, peringkat nilai piutang di KPP, dan kualitas piutang. Pemberian skor risiko didasarkan pada pedoman berikut.

1) Dari segi umur piutang, risiko ketidaktertagihan dinilai rendah apabila umur piutang kurang dari 1 tahun; dinilai sedang apabila umur piutang 1 s.d. 3 tahun; dan dinilai tinggi apabila umur piutang lebih dari 3 tahun.

2) Dari segi peringkat piutang di KPP, risiko ketidaktertagihan dianggap rendah jika piutang termasuk $50 \%$ peringkat teratas; dianggap sedang jika termasuk $40 \%$ peringkat berikutnya; dan dianggap tinggi jika termasuk $10 \%$ peringkat terbawah.

3) Dari sisi kualitas piutang berdasarkan PER02/PJ/2012, risiko ketidaktertagihan dipandang rendah jika piutang termasuk kategori lancar; dipandang sedang jika piutang termasuk kategori kurang lancar; dan dipandang tinggi jika piutang termasuk kategori diragukan atau macet.

Parameter kedua dalam analisis ketidaktertagihan adalah tingkat ketertagihan yang didasarkan pada riwayat pelaporan, riwayat pembayaran, riwayat pemeriksaan, kondisi usaha WP, dan status atau kondisi Penanggung Pajak. Pemberian skor risiko didasarkan pada pedoman berikut.

1) Dari segi riwayat pelaporan, risiko ketidaktertagihan dianggap rendah jika Wajib Pajak selalu melaporkan SPT Tahunan PPh Badan/PPh OP (untuk WP domisili) dan SPT Masa
PPh Pasal 21/Pasal 23/Pasal 4 ayat (2) (untuk WP lokasi) dalam dua tahun terakhir; dianggap sedang jika Wajib Pajak pernah melaporkan SPT tersebut di atas dalam dua tahun terakhir; dan dianggap tinggi jika Wajib Pajak tidak melaporkan SPT tersebut di atas dalam dua tahun terakhir

2) Dari segi riwayat pembayaran, risiko ketidaktertagihan dianggap rendah dalam hal terdapat pembayaran pajak dalam dua tahun berturut-turut; dianggap sedang dalam hal terdapat pembayaran pajak dalam dua tahun terakhir; dan dianggap tinggi dalam hal tidak terdapat pembayaran pajak dalam dua tahun terakhir.

3) Dari segi riwayat pemeriksaan, risiko ketidaktertagihan dianggap rendah dalam hal Wajib Pajak diperiksa dalam dua tahun berturutturut; dianggap sedang dalam hal Wajib Pajak pernah diperiksa dalam dua tahun terakhir; dan dianggap tinggi dalam hal Wajib Pajak tidak pernah diperiksa dalam dua tahun terakhir.

4) Dari segi kondisi usaha Wajib Pajak, risiko ketidaktertagihan dianggap rendah jika Wajib Pajak beroperasi normal; dianggap sedang jika Wajib Pajak Wajib Pajak tidak beroperasi normal atau dalam sengketa (permohonan pailit/PKPU, dan lain-lain); dan dianggap tinggi jika Wajib Pajak pailit; dalam likuidasi; atau meninggal dunia (WP OP).

5) Dari segi kondisi Penanggung Pajak, risiko ketidaktertagihan dianggap rendah bila Apabila Wajib Pajak/Penanggung Pajak bersikap cukup kooperatif terhadap upaya-upaya persuasif Juru 
Sita dan menunjukkan itikad baik, responsif terhadap tindakan penagihan aktif, Penanggung Pajak relatif mudah dihubungi dan diketahui keadaannya. Sementara itu risiko dianggap sedang jika Wajib Pajak/Penanggung Pajak bersikap kurang kooperatif, tidak responsif terhadap penagihan aktif, dan Penanggung Pajak diketahui keberadaannya namun sulit dihubungi. Namun jika Wajib Pajak/Penanggung Pajak bersikap tidak kooperatif dan tidak menunjukkan itikad baik, memberikan respon negatif terhadap penagihan aktif, dan Penanggung Pajak tidak dapat dihubungi dan tidak diketahui keberadaannya; risiko ketidaktertagihan dianggap tinggi.

Parameter ketiga yang dijadikan acuan dalam mengukur risiko ketidaktertagihan adalah kemampuan membayar WP (ability to pay) yang dinilai dari keberadaan dan nilai aset Wajib Pajak serta Penanggung Pajak. Berikut adalah pedoman pemberian skor risiko ketidaktertagihan piutang berdasarkan parameter tersebut.

1) Dari segi keberadaan dan nilai aset WP, risiko ketidaktertagihan dinilai rendah bila terdapat aset dan nilainya sama dengan atau melebihi nilai piutang; dinilai sedang bila terdapat aset namun nilainya kurang dari nilai piutang; dan dinilai tinggi bila tidak ada aset yang dimiliki WP.

2) Dari segi keberadaan dan nilai aset Penanggung Pajak, risiko ketidaktertagihan dinilai rendah bila terdapat aset dan nilainya sama dengan atau melebihi nilai piutang; dinilai sedang bila terdapat aset namun nilainya kurang dari nilai piutang; dan dinilai tinggi bila tidak ada aset yang dimiliki Penanggung Pajak.

Dengan acuan pemberian skor yang telah dijelaskan di atas, tiap-tiap Wajib Pajak yang memiliki tunggakan pajak yang signifikan (atau paling tidak berada dalam Daftar 100 Penunggak Pajak Terbesar) dianalisis dan dihitung skor risiko ketidaktertagihan tunggakannya. Berdasarkan jumlah final skor dari ketiga parameter tersebut, seluruh Wajib Pajak tersebut diperingkatkan agar diketahui urutan prioritasnya. Informasi terkait urutan prioritas tersebut dituangkan dalam DPTPP yang akan menjadi panduan bagi Juru Sita Pajak dalam menentukan sasaran tindakan penagihan. Skor tersebut kemudian dijadikan dasar untuk mengelompokkan Wajib Pajak sebagaimana dijelaskan dalam Tabel 4.

Tabel 4 Pengelompokan Wajib Pajak berdasarkan Skala Prioritas

\begin{tabular}{|l|l|}
\hline \multicolumn{1}{|c|}{ Prioritas } & \multicolumn{1}{|c|}{ Keterangan } \\
\hline Prioritas I & Kelompok Wajib Pajak yang memiliki risiko ketidaktertagihan piutang pajak rendah (total skor $>70)$ \\
\hline Prioritas II & Kelompok Wajib Pajak yang memiliki risiko ketidaktertagihan piutang pajak sedang $(40<$ total skor $<70)$ \\
\hline Prioritas III & Kelompok Wajib Pajak yang memiliki risiko ketidaktertagihan piutang pajak tinggi (total skor $<40$ ) \\
\hline
\end{tabular}
Sumber: Lampiran SE-29/PJ/2012.

Pedoman tersebut berlaku untuk piutang yang tidak mendekati daluwarsa penagihan. Sebab, dalam hal piutang akan daluwarsa dalam tahun berjalan, Wajib Pajak akan langsung dimasukkan dalam kelompok prioritas I dengan mengabaikan total skor yang dimiliki.

Dari penjelasan di atas dapat diambil simpulan bahwa proses analisis dan penilaian risiko berdasarkan SE-29/PJ/2012 merupakan proses panjang yang memakan cukup banyak waktu. Kepingan informasi yang diperlukan untuk melengkapi matriks penilaian risiko tersebut cukup banyak dan harus dikumpulkan oleh KPP secara manual dengan mengakses berbagai sumber informasi yang berbeda. Riwayat pelaporan dan pembayaran misalnya, dapat dicari melalui Sistem Informasi Direktorat Jenderal Pajak (SIDJP), namun peringkat nilai piutang Wajib Pajak hanya dapat diketahui setelah terlebih dahulu dilakukan penarikan dan pengolahan data master file piutang Wajib Pajak dalam satu KPP. Data tentang keberadaan dan nilai aset Wajib Pajak juga perlu digali dari daftar harta yang dilaporkan dalam SPT Tahunan. Dan dalam hal Wajib Pajak tidak melaporkan harta apa pun dalam SPT Tahunannya, Juru Sita perlu bekerja lebih keras untuk menggali informasi terkait aset yang dimilikinya. Misalnya dengan mencari tahu rekening yang kemungkinan merupakan milik WP dengan melacak pembayaran yang dilakukannya dalam MPN. Sementara itu, aset Penanggung Pajak yang terdaftar di
KPP yang berbeda dengan Wajib Pajak hanya bisa dilihat melalui Approweb.

Akibatnya, banyak KPP di wilayah Kanwil Jatim I yang tidak membuat DPTPP berdasarkan ketentuan penyusunan KKARKPP sebagaimana dijelaskan di atas. KPP memiliki sumber daya manusia dan waktu yang terbatas sehingga pembuatan DPTPP dengan langkahlangkah tersebut tidak memungkinkan untuk dilakukan. Namun, tidak dibuatnya KKARKPP dan DPTPP berdasarkan SE-29/PJ/2012 tersebut tidak berarti bahwa konsep manajemen risiko dalam penagihan pajak sama sekali diabaikan oleh KPP. Dalam menentukan prioritas tindakan penagihan KPP tetap memiliki beberapa acuan yang secara konsisten diterapkan. Hampir seluruh informan dari berbagai KPP menyepakati bahwa acuan utama yang mereka gunakan dalam memprioritaskan tindakan penagihan adalah besarnya nominal tunggakan pajak. Dalam hal ini, KPP secara berkala mengunduh data master file piutang pajak dari SIDJP dan mengolahnya sehingga didapatkan Daftar 100 Penunggak Pajak Terbesar. Daftar tersebut kemudian didistribusikan kepada tiaptiap Juru Sita Pajak berdasarkan pembagian wilayah kerja yang telah disepakati untuk ditindaklanjuti. Halhal yang kemudian menjadi pertimbangan dari tiaptiap Juru Sita Pajak pun beragam, namun tetap tidak lepas dari konsep manajemen risiko sebagaimana ditentukan dalam SE-29/PJ/2012. Juru Sita Pajak tetap mempertimbangkan aspek karakteristik piutang dengan menilai nominal, umur, dan kualitas piutang; 
menggali aspek kepatuhan atau kecenderungan membayar dengan mengidentifikasi keberadaan WP/Penanggung Pajak, riwayat pelaporan, riwayat pembayaran, riwayat pemeriksaan, dan menilai tingkat kooperasi Wajib Pajak/Penanggung Pajak; serta mengukur kemampuan bayar dengan mencari tahu kondisi operasi usaha WP atau ada tidaknya aset yang dimilikinya maupun Penanggung Pajaknya. Juru Sita Pajak juga mempertimbangkan apakah suatu tunggakan pajak akan segera mengalami daluwarsa penagihan. Namun karena keberagaman karakter dan kapasitas dari Juru Sita Pajak, pembuatan daftar prioritas tindakan penagihan dengan model semacam ini tentu bersifat subjektif dan arbitrer.

\subsubsection{Perubahan Proses Bisnis yang Diharapkan}

Berdasarkan Surat Edaran Dirjen Pajak Nomor SE24/PJ/2019 tentang tentang Implementasi Compliance Risk Management dalam Kegiatan Ekstensifikasi, Pengawasan, Pemeriksaan, dan Penagihan di Direktorat Jenderal Pajak, dalam rangka mengoptimalkan pencairan piutang pajak, KPP wajib menetapkan prioritas penagihan dengan mengacu pada Daftar Prioritas Tindakan Penagihan Pajak (DPTPP). DPTPP tersebut disusun menggunakan CRM Fungsi Penagihan. Luaran atau output dari CRM Fungsi Penagihan adalah Daftar Prioritas Tindakan dan Daftar Prioritas Pencairan sebagaimana telah dijelaskan sebelumnya. DPTPP tersebut kemudian ditindaklanjuti sesuai urutan risiko masing-masing Wajib Pajak atau sesuai kebijakan dengan pertimbangan Kepala Kantor sesuai dengan ketentuan dalam Undang-undang Nomor 19 Tahun 1997 tentang Penagihan Pajak Dengan Surat Paksa sebagaimana telah diubah dengan Undang-undang Nomor 19 Tahun 2000.

Dengan diluncurkannya CRM Fungsi Penagihan pada tahun 2019, diharapkan terjadi perubahan proses bisnis dalam penentuan prioritas tindakan penagihan dari yang semula dilakukan secara manual menjadi otomatis. CRM diharapkan dapat meningkatkan efektivitas dan efisiensi dari proses penetapan prioritas penagihan dengan menyediakan nilai risiko penagihan dari semua penunggak pajak dalam suatu KPP. Gambar 3 menunjukkan perubahan proses bisnis yang diharapkan setelah CRM Fungsi Penagihan diluncurkan.

Gambar 3 Perubahan Proses Bisnis yang Diharapkan Setelah Adanya CRM

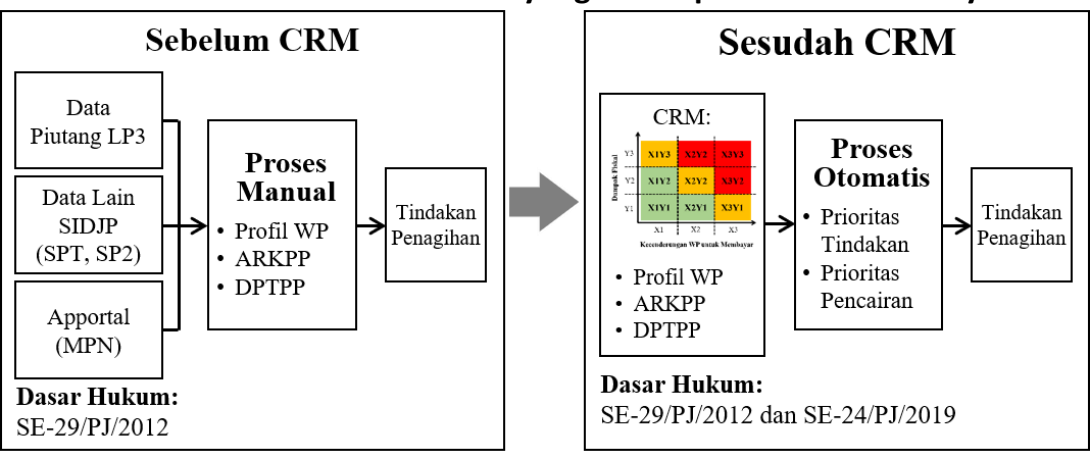

Sumber: Diolah Penulis dari Bahan Tayang Bimbingan Teknis CRM

Gambar 3 menjelaskan bahwa sebelum diluncurkannya CRM, dalam menyusun DPTPP, KPP harus terlebih dulu membuat profil Wajib Pajak. Data dalam profil Wajib Pajak tersebut kemudian akan menjadi pertimbangan dalam analisis ketidaktertagihan tunggakan pajak yang dituangkan dalam KKARKPP yang disusun paling tidak setahun sekali dan disesuaikan dalam tahun berjalan. Kemudian dari KKARKPP itulah DPTPP dihasilkan. Sementara itu, setelah diluncurkannya CRM, penyusunan DPTPP secara manual tidak perlu dilakukan lagi karena DPTPP dapat dihasilkan secara otomatis oleh risk engine yang memetakan serta mengkalkulasi skor risiko penagihan tiap-tiap Wajib Pajak berdasarkan variabel dan datadata yang diperlukan.

\subsubsection{Kelemahan CRM Fungsi Penagihan}

Berdasarkan fakta yang ditemukan di Kanwil Jatim I, perubahan proses bisnis secara signifikan sebagaimana dipaparkan di atas tersebut belum terjadi. Sebab terdapat kelemahan dalam CRM Fungsi Penagihan yang membuatnya tidak dapat dijadikan sebagai DSS utama dalam penentuan prioritas.

Pemutakhiran data dalam CRM Fungsi Penagihan jauh lebih lambat dibandingkan dengan data dalam sistem informasi utama yang digunakan di
DJP (SIDJP). SIDJP dapat menyajikan data Wajib Pajak secara real-time, sedangkan CRM Fungsi Penagihan hanya melakukan pemutakhiran data setiap beberapa bulan sekali. Padahal basis dari tindakan penagihan adalah piutang yang memiliki karakteristik unik, yaitu sifat yang dinamis. Saldo dari piutang pajak bisa berubah-ubah sepanjang waktu baik karena pelunasan, pengurangan sanksi, pembatalan ketetapan, dan lain sebagainya. Piutang pajak yang belum ada di pagi hari ini bisa jadi muncul keesokan harinya atau bahkan saat sore di hari yang sama. Sebaliknya, piutang pajak yang eksis hari ini bisa jadi hilang di hari yang sama pula karena adanya pembayaran tunggakan pajak yang dilakukan oleh WP. Maka, data yang terkait dengan piutang pajak seharusnya dimutakhirkan sepanjang waktu agar dapat mengikuti sifatnya yang terus berubah-ubah. Oleh karena itu, pemutakhiran data CRM yang dilakukan setiap beberapa bulan sekali menjadikan data tunggakan WP dan nilai risiko yang dihasilkan berdasarkan data tersebut tidak selalu relevan dengan kondisi WP yang sesungguhnya.

Selain itu, pengguna dari CRM Fungsi Penagihan di Kanwil Jatim I mengalami beberapa gangguan dalam mengakses data CRM. Pada saat CRM 
diluncurkan, yaitu September 2019, peta risiko beserta rincian data tiap kuadran hanya bisa diakses oleh Kepala Seksi Penagihan. Juru Sita Pajak belum bisa mengakses data tersebut. Tidak lama kemudian, peta risiko dan data WP tiap kuadran bisa diakses baik oleh Kepala Seksi Penagihan maupun Juru Sita Pajak, namun tidak dapat diekspor ke dalam bentuk Microsoft Excel sehingga pengguna harus melakukan salin-tempel secara manual dari laman CRM untuk melakukan penyedotan data. Di tahun 2020, data CRM dapat diekspor ke format Microsoft Excel sehingga memudahkan pengguna dalam mengunduh data. Namun di bulan Juni s.d. Agustus 2021 beberapa KPP melaporkan kendala bahwa ekspor data CRM kembali tidak dapat dilakukan, bahkan salah satu KPP mengaku bahwa data rincian tiap kuadran peta risiko sama sekali tidak dapat diakses. Kendala-kendala tersebut membuat CRM Fungsi Penagihan sulit diandalkan sebagai DSS dalam penentuan prioritas tindakan penagihan.

Kemudian ditemukan pula beberapa pengguna yang masih mengalami misinterpretasi data. Sebagai risk engine kegiatan penagihan, CRM Fungsi Penagihan memetakan seluruh Wajib Pajak yang memiliki tunggakan pajak ke dalam sembilan kuadran berdasarkan parameter dampak fiskal dan kecenderungan membayar. Semakin tinggi letak suatu kuadran, semakin tinggi pula dampak fiskal atau nominal piutang pajak. Sementara itu, semakin ke kiri letak suatu kuadran, semakin tinggi pula kecenderungan WP untuk membayar. Namun tidak semua Juru Sita Pajak dan Kepala Seksi P3 menginterpretasikan peta risiko sebagaimana penjelasan tersebut. Berdasarkan informasi dari observasi dan wawancara, beberapa informan masih mengalami misinterpretasi arti dari sumbu $X$ peta risiko. Sebagian informan menganggap bahwa WP dalam kuadran dengan warna hijau memiliki likuiditas yang tinggi. Akibatnya mereka kerap memprioritaskan tindakan penagihan untuk WP dalam kuadran hijau tersebut. Beberapa informan juga memiliki anggapan bahwa WP dalam kuadran dengan warna merah adalah WP dengan tunggakan yang macet. Padahal WP dalam kuadran tersebut justru seharusnya dianggap memiliki kemampuan pelunasan tunggakan yang tinggi dan harus diprioritaskan dibandingkan WP dalam kuadran lainnya. Di sisi lain misinterpretasi ini timbul karena nyatanya data-data dalam kuadran tersebut memang tidak selalu akurat. Misalnya, WP A ditempatkan di kuadran X3Y3 karena risk engine mengidentifikasinya sebagai WP yang memiliki nilai tunggakan dan kemampuan membayar yang tinggi. Namun, risk engine menganggap WP tersebut berkemampuan membayar tinggi berdasarkan data histori pembayaran yang terlalu lampau. Padahal berdasarkan kondisi terbaru saat ini, WP sudah tidak beroperasi lagi dan baik WP maupun para Penanggung Pajaknya sudah tidak memiliki aset yang dapat disita untuk melunasi utang pajaknya. Adanya misinterpretasi semacam ini tentu membuat penetapan prioritas yang dilakukan berdasarkan data CRM menjadi tidak konsisten. Kesalahpahaman tersebut membuat CRM Fungsi Penagihan masih belum bisa dijadikan sebagai DSS otomatis sebagaimana ditentukan dalam SE-24 Tahun 2019.

\subsubsection{Alur Pemanfaatan CRM Fungsi Penagihan}

Sehubungan dengan ketiga kelemahan dari CRM Fungsi Penagihan sebagai DSS yang telah dijelaskan di atas, baik Juru Sita Pajak maupun Kepala Seksi P3 di Kanwil Jatim I sejauh ini belum menempatkan data CRM Fungsi Penagihan-baik Daftar Prioritas Tindakan maupun Daftar Prioritas Pencairan-sebagai DSS utama dalam penyusunan DPTPP. Untuk meminimalisasi piutang daluwarsa, Juru Sita Pajak masih menggunakan data yang ada dalam SIDJP karena data tersebut lebih mutakhir dibandingkan Daftar Prioritas Tindakan yang disajikan dalam CRM. Preferensi tersebut sebenarnya wajar mengingat ketetapan yang akan daluwarsa penagihan perlu ditindaklanjuti dengan segera. Maka, memilih data dengan akurasi dan tingkat kemutakhiran yang lebih andal merupakan keputusan yang bijak.

Sementara untuk tujuan pencairan, penetapan prioritas tindakan penagihan tetap didominasi cara manual dengan acuan SE-29/PJ/2012 tentang Kebijakan Penagihan Pajak. Daftar Prioritas Pencairan yang disediakan CRM hanya berfungsi sebagai trigger (pemicu) yang bersifat sebagai data tambahan saja. Data pemicu tersebut pun belum dapat digunakan secara serta-merta. Daftar Prioritas Pencairan CRM masih perlu diolah terlebih dahulu dan disandingkan dengan data terbaru dari SIDJP untuk memastikan validitasnya.

\section{Gambar 4 Alur Pemanfaatan Daftar Prioritas Pencairan CRM}

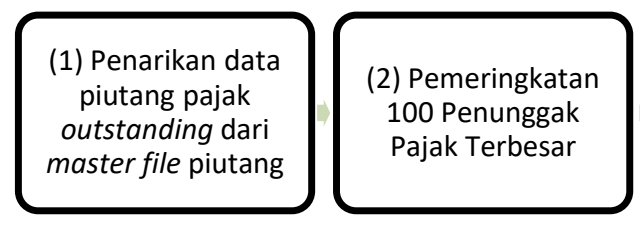

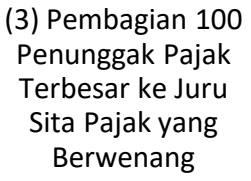

(3) Pembagian 100 Penunggak Pajak Terbesar ke Juru Sita Pajak yang Berwenang

(4) Melakukan

Analisis Risiko

Ketertagihan atas

100 Pengunggak

Pajak Terbesar

\section{(9) Penyesuaian dan Penetapan Prioritas Tindakan Penagihan Final}

(8) Pengecekan Validitas Data dari CRM
(7) Penyandingan Data CRM dengan Prioritas Tindakan Penagihan yang Sudah Ditetapkan
(6) Pengunduhan

Daftar Prioritas

Pencairan dari CRM
(5) Penetapan Prioritas Tindakan Penagihan berdasarkan Analisis Risiko Ketertagihan 
Alur pemanfaatan data CRM dalam penentuan prioritas tindakan penagihan yang dilakukan di Kanwil DJP Jatim I sebagaimana dirangkum dalam Gambar 4 dapat dijelaskan sebagai berikut.

1) Juru Sita Pajak melakukan penarikan data piutang pajak outstanding dari master file piutang yang tersedia dalam SIDJP. Proses ini menghasilkan luaran berupa daftar seluruh tunggakan pajak yang dimiliki semua Wajib Pajak yang terdaftar di KPP.

2) Juru Sita Pajak mengolah data piutang pajak outstanding sehingga dihasilkan Daftar 100 Penunggak Pajak Terbesar. Daftar tersebut disajikan berdasarkan urutan nominal tunggakan pajak dari yang terbesar hingga yang terkecil.

3) Daftar 100 Penunggak Pajak Terbesar dibagikan kepada tiap-tiap Juru Sita Pajak yang berwenang sebagaimana pembagian wilayah kerja yang sudah disepakati.

4) Juru Sita Pajak secara individu melakukan analisis ketertagihan tunggakan pajak yang dimiliki Wajib Pajak dalam Daftar 100 Penunggak Pajak Terbesar berdasarkan parameter manajemen risiko yang ada dalam SE-29/PJ/2012 tentang Kebijakan Penagihan Pajak. Parameter yang dipertimbangkan antara lain adalah karakteristik piutang seperti nominal, umur, dan kualitas piutang. Juru Sita juga mempertimbangkan aspek kepatuhan atau kecenderungan membayar (tendency to pay). Untuk menentukan aspek tersebut Juru Sita mengidentifikasi keberadaan WP/Penanggung Pajak serta mempelajari riwayat pelaporan, riwayat pembayaran, riwayat pemeriksaan, dan tingkat kooperasi Wajib Pajak/Penanggung Pajak. Hal penting lainnya yang menjadi pertimbangan Juru Sita adalah kemampuan bayar (ability to pay). Untuk memahami aspek tersebut, Juru Sita mencari tahu kondisi operasi usaha WP atau ada tidaknya aset yang dimilikinya maupun Penanggung Pajaknya baik melalui data SPT Tahunan, data rekening di Approweb, data eksternal, maupun dengan kunjungan langsung ke lapangan.

5) Berdasarkan analisis ketertagihan yang dilakukan Juru Sita menetapkan daftar prioritas tindakan penagihan yang akan digunakan sebagai acuan dalam rencana kegiatan penagihan.

6) Juru Sita Pajak kemudian mengecek apakah telah terdapat data Daftar Prioritas Pencairan baru dalam CRM Fungsi Penagihan. Dalam hal data CRM Fungsi Penagihan telah dimutakhirkan, Juru Sita Pajak mengunduh data yang ada. Dalam kondisi ideal, data yang disediakan CRM dapat secara langsung diekspor ke dalam format Microsoft Excel. Namun Juru Sita masih sering kali harus melakukan salin-tempel secara manual karena data yang ada tidak dapat diekspor secara langsung.

7) Setelah data CRM diunduh, Juru Sita Pajak menyandingkan data tersebut dengan daftar prioritas tindakan penagihan yang sudah dibuat. Apabila terdapat Wajib Pajak dengan kuadran berwarna merah atau nominal tunggakan yang tinggi yang belum dimasukkan ke dalam daftar prioritas tindakan, Wajib Pajak tersebut akan dipertimbangkan untuk diikutsertakan dalam daftar tersebut setelah diperiksa kembali validitasnya.

8) Atas 'data tambahan' yang diperoleh dari langkah sebelumnya, Juru Sita Pajak melakukan pengecekan untuk memastikan validitasnya. Data yang dijadikan acuan untuk pengecekan ini adalah master file piutang yang telah diunduh sebelumnya. Pertama, Juru Sita memeriksa eksistensi tunggakan untuk memastikan bahwa status ketetapan pajak masih kurang bayar. Setelah itu Juru Sita memastikan tindakan penagihan terakhir yang telah dilakukan atas ketetapan pajak. Pengecekan tersebut diperlukan karena data yang disediakan CRM tidak selalu mutakhir. Selain itu, Juru Sita biasanya juga akan memeriksa apakah Wajib Pajak memang layak berada dalam suatu kuadran dari peta risiko. Hal ini dilakukan terutama untuk Wajib Pajak yang berada dalam kuadran berwarna merah (X3Y3, $\mathrm{X} 2 \mathrm{Y}_{3}$, dan X3Y2) yang dianggap memiliki dampak fiskal serta kemampuan membayar yang tinggi. Juru Sita akan mendalami apakah Wajib Pajak dalam kuadran tersebut memang memiliki kemampuan membayar yang tinggi dengan mengumpulkan berbagai informasi terkait kondisi usaha dan aset yang dimiliki Wajib Pajak/Penanggung Pajak.

9) Apabila 'data tambahan' dari CRM sudah valid, data tersebut dapat dimasukkan ke dalam daftar prioritas tindakan pajak. Daftar prioritas final tersebut akan menjadi bagian dari rencana kegiatan penagihan yang akan dilakukan oleh Juru Sita Pajak. Daftar tersebut dapat disesuaikan dengan perkembangan informasi yang diperoleh Juru Sita Pajak.

Demikianlah langkah-langkah yang umumnya dilakukan dalam rangka pemanfaatan data CRM Fungsi Penagihan di Kanwil Jatim I untuk membuat DPTPP. Penetapan DPTPP ini umumnya dilakukan satu sampai dengan dua bulan sekali. Dan karena data dalam CRM Fungsi Penagihan tidak selalu dimutakhirkan secara berkala, pembuatan DPTPP terkadang hanya melibatkan langkah pertama sampai dengan kelima. Penetapan DPTPP dengan proses tersebut sejatinya tidak berbeda dengan alur penetapan DPTPP yang telah dilakukan sebelum diluncurkannya CRM Fungsi Penagihan.

\subsection{Skor Usability CRM sebagai DSS dalam Melaksanakan Kegiatan Penagihan di Kanwil DJP Jatim I berdasarkan Usability Inquiry}

Untuk menentukan skor usability CRM sebagai

DSS dalam melaksanakan kegiatan penagihan, kuesioner disusun berdasarkan enam aspek kegunaan (usability) yang terdiri atas efektivitas, efisiensi, akurasi, understandability, operability, dan learnability (Shafinah et al., 2010). Kuesioner tersebut telah dibagikan kepada 28 Juru Sita Pajak di lingkungan Kanwil DJP Jatim I. Dalam mengisi kuesioner, responden diminta memberikan pendapat 
atas tiga belas pernyataan terkait CRM (tiga pernyataan untuk aspek efektivitas dan dua pernyataan untuk tiap-tiap aspek lainnya) dengan skala 1 sampai dengan 5 .

\subsubsection{Aspek Efektivitas}

Aspek efektivitas diwakili oleh tiga pernyataan berikut: CRM mendukung optimalisasi pencairan piutang pajak (Q1); CRM mendukung pengambilan keputusan dalam menentukan prioritas tindakan penagihan (Q2); dan CRM menyediakan informasi yang jelas tentang profil risiko Wajib Pajak (Q3). Merit tiaptiap pernyataan tersebut adalah sebagai berikut: Q1 sebesar 0,77; Q2 sebesar 0,80; dan Q3 sebesar 0,73 sehingga merit rata-rata untuk aspek efektivitas adalah sebesar 0,77. Hasil tersebut menunjukkan bahwa sebagai DSS, CRM merupakan sistem yang "baik" dalam mencapai tujuan tertentu yang telah ditetapkan.

\subsubsection{Aspek Efisiensi}

Aspek efisiensi diwakili oleh dua pernyataan berikut: CRM membantu mempercepat pembuatan prioritas tindakan penagihan (Q3); dan CRM selalu menyediakan data yang mutakhir (up-to-date) secara berkala (Q4). Berdasarkan hasil dari kuesioner, merit dari Q4 mencapai 0,81 sedangkan merit dari Q5 mencapai 0,70; sehingga merit rata-rata untuk aspek efisiensi adalah sebesar 0,75. Hasil tersebut menunjukkan bahwa CRM sudah berada pada level "baik" dalam menghemat waktu penggunanya untuk menentukan prioritas tindakan penagihan.

\subsubsection{Aspek Akurasi}

Aspek akurasi diwakili oleh dua pernyataan berikut: CRM menyediakan profil risiko yang sesuai dengan kondisi nyata Wajib Pajak (Q6); dan CRM memiliki kriteria yang cukup untuk pengambilan keputusan dalam menentukan prioritas tindakan penagihan (Q7). Berdasarkan hasil dari kuesioner, merit dari Q6 mencapai 0,67 sedangkan merit dari Q7 mencapai 0,76; sehingga merit rata-rata untuk aspek akurasi adalah sebesar 0,71. Hasil tersebut menunjukkan bahwa CRM sudah berada pada level "baik" dalam menyediakan informasi yang cukup untuk pengambilan keputusan dalam membuat prioritas tindakan penagihan.

\subsubsection{Aspek Understandability}

Aspek keterpahaman diwakili oleh dua pernyataan berikut: istilah yang digunakan sistem CRM sederhana dan mudah dimengerti (Q8); dan tampilan sistem serta alur penggunaan CRM jelas dan mudah dipahami (Q9). Berdasarkan hasil dari kuesioner, merit dari Q8 mencapai 0,79 sedangkan merit dari Q9 mencapai 0,81; sehingga merit rata-rata untuk aspek keterpahaman adalah sebesar 0,80. Hasil tersebut menunjukkan bahwa sebagai suatu DSS, CRM sudah berada pada level "baik" dari segi kemudahan untuk dipahami.

\subsubsection{Aspek Kemudahan Operasi (Operability)}

Aspek operability diwakili oleh dua pernyataan berikut: CRM mudah untuk dioperasikan (Q10) dan CRM dapat dioperasikan kapan saja (Q11). Berdasarkan hasil dari kuesioner, merit dari Q10 mencapai 0,83 sedangkan merit dari Q11 mencapai 0,80; sehingga merit rata-rata untuk aspek kemudahan operasi adalah sebesar 0,82. Hasil tersebut menunjukkan bahwa sebagai suatu DSS, CRM sudah berada pada level "sangat baik" dalam hal kemudahan operasi.

4.2.6 Aspek Kemudahan untuk Dipelajari
(Learnability)

Aspek learnability diwakili oleh dua pernyataan berikut: cara penggunaan CRM mudah untuk dipelajari (Q12); dan istilah dan kegunaan perintah (command) dalam sistem CRM mudah diingat (Q13). Berdasarkan hasil dari kuesioner, merit dari Q12 mencapai 0,81 sedangkan merit dari Q13 mencapai 0,77; sehingga merit rata-rata untuk aspek learnability adalah sebesar 0,79. Hasil tersebut menunjukkan bahwa sebagai suatu DSS, CRM sudah berada pada level "baik" dalam hal kemudahan untuk dipelajari.

\section{Gambar 5 Merit Rata-Rata Enam Aspek Usability CRM Fungsi Penagihan}

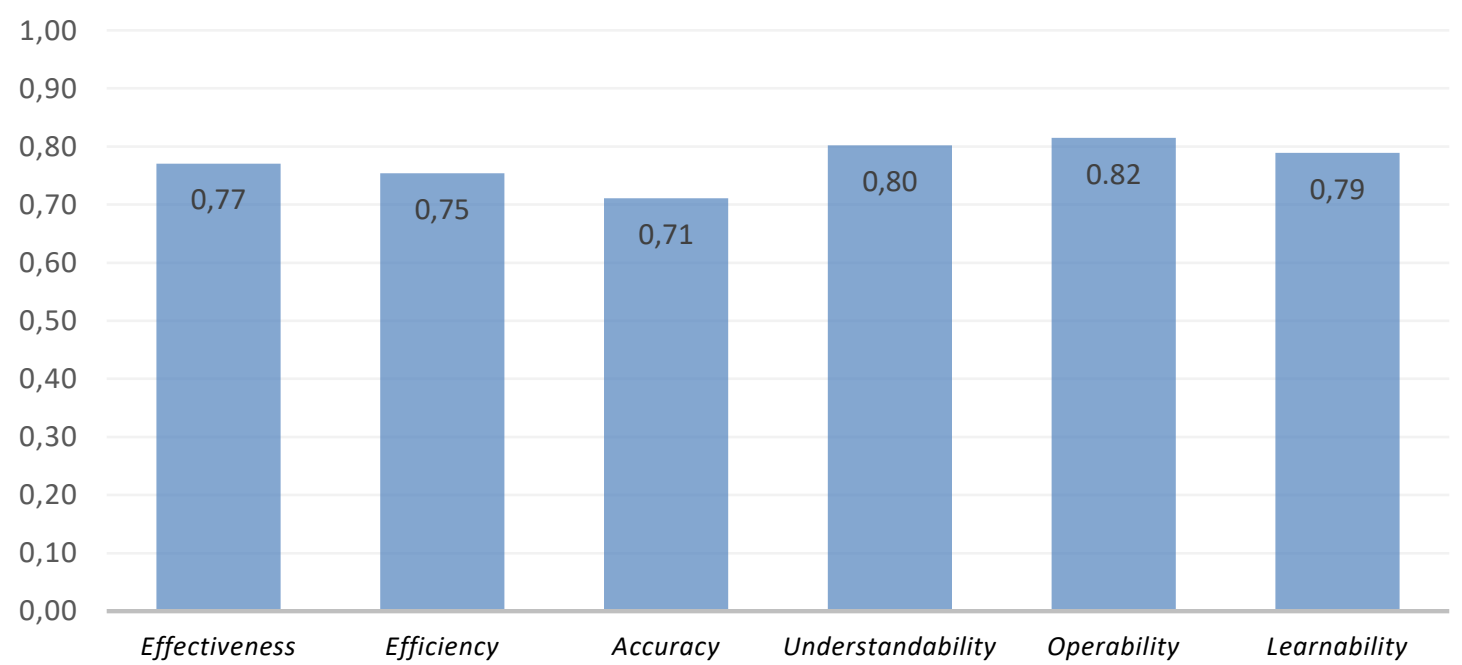

Sumber: Diolah Penulis 


\subsection{Hasil Evaluasi Tingkat Kegunaan CRM sebagai DSS dalam Melaksanakan Kegiatan Penagihan di Kanwil DJP Jatim I berdasarkan Usability Inquiry}

Setelah dilakukan penyebaran kuesioner untuk memperoleh skor usability dari CRM sebagai DSS, evaluasi diperdalam lagi melalui wawancara kepada informan dan observasi untuk memperluas pemahaman tentang tingkat kegunaan CRM dalam penetapan prioritas tindakan penagihan di Kanwil DJP Jatim I.

\subsubsection{Aspek Efektivitas}

Terkait penyediaan informasi profil risiko Wajib Pajak, CRM secara umum telah cukup membantu memetakan risiko penagihan dari Wajib Pajak dengan kodifikasi merah-kuning-hijau yang mudah dipahami. Namun ada kalanya, informasi terkait nilai risiko yang diberikan masih kurang akurat. Contohnya, Wajib Pajak di kuadran X3Y3 yang seharusnya memiliki kemampuan membayar yang tinggi pada kenyataannya sudah mengalami pailit dan tidak lagi memiliki aset untuk melunasi tunggakannya. Hal semacam ini bisa jadi disebabkan oleh penggunaan data historis yang sudah tidak relevan untuk dijadikan sebagai penentu kemampuan membayar. Misalnya, risk engine mengidentifikasi bahwa terdapat data pembayaran dalam jumlah besar di MPN beberapa tahun yang lalu. Data tersebut kemudian menjadi pemicu yang membuat Wajib Pajak dikategorikan memiliki kemampuan membayar yang tinggi. Padahal pembayaran tersebut dilakukan saat kondisi operasi perusahaan Wajib Pajak masih berlangsung dengan baik, sedangkan pada saat ini Wajib Pajak sudah bangkrut dan tidak memiliki aset yang dapat disita.

Dalam hal pengambilan keputusan untuk menetapkan daftar prioritas tindakan penagihan, beberapa informan mengaku bahwa CRM telah membantu meningkatkan kualitas dari DPTPP yang mereka susun dalam rangka mengejar target pencairan piutang pajak. Namun, data CRM yang telah dimanfaatkan selama ini hanyalah data dalam Daftar Prioritas Pencairan. Selain itu, pemanfaatan data tersebut dalam penetapan DPTPP selama ini adalah sebagai trigger atau data tambahan bagi Juru Sita Pajak. Data tambahan tersebut sejauh ini dirasa cukup membantu meningkatkan kualitas dari DPTPP yang disusun oleh Juru Sita Pajak. Sementara itu, data dalam Daftar Prioritas Tindakan-yang terdiri atas Wajib Pajak dengan tunggakan pajak yang akan mengalami daluwarsa penagihan dalam 12 bulan-belum dimanfaatkan. Juru Sita Pajak mengaku bahwa data ketetapan yang akan daluwarsa yang disediakan dalam menu Informasi dan Monitoring di SIDJP jauh lebih mutakhir dan mudah digunakan. Data dari menu tersebut dapat diakses berdasarkan tahun pajak dan hal tersebut memudahkan Juru Sita untuk menentukan ketetapan yang harus didahulukan untuk ditindaklanjuti.

Sementara itu, dari sisi kontribusi terhadap pencairan piutang pajak, CRM tidak membawa dampak yang signifikan. Tabel 5 menunjukkan perbandingan antara capaian pencairan piutang pajak tahun 2019 sebelum CRM mulai benar-benar digunakan di Kanwil DJP Jatim I dengan capaian pencairan piutang pajak di tahun 2020. Data dalam tabel tersebut menunjukkan bahwa 9 dari 12 KPP yang beroperasi justru mengalami pertumbuhan capaian pencairan piutang pajak yang minus. Bahkan 8 di antaranya memiliki persentase capaian pencairan piutang di bawah $50 \%$. Hal ini menunjukkan bahwa alih-alih menyederhanakan proses penetapan prioritas tindakan penagihan, adanya CRM Fungsi Penagihan justru memperpanjang proses penetapan prioritas. Hal ini menyebabkan pencapaian pencairan piutang pajak menurun.

Tabel 5 Capaian Pencairan Piutang Pajak Tahun 2019 dan 2020

\begin{tabular}{|c|l|r|r|r|c|c|}
\hline \multirow{2}{*}{ No Unit Kerja } & \multicolumn{1}{|c|}{ Target dan Capaian 2020 } & \multicolumn{2}{c|}{ Pertumbuhan } \\
\cline { 3 - 6 } & & Target & Capaian & $\begin{array}{c}\text { Persen } \\
(\%)\end{array}$ & $\begin{array}{c}\text { Capaian } \\
2019\end{array}$ & $\begin{array}{c}\text { Persen } \\
(\%)\end{array}$ \\
\hline 1 & KPP Madya Dua Surabaya & \multicolumn{3}{|c|}{ (Baru beroperasi 24 Mei 2021) } \\
\hline 2 & KPP Madya Surabaya & 117.360 .363 & 167.072 .721 & $142 \%$ & 48.901 .223 & $242 \%$ \\
\hline 3 & KPP Pratama Surabaya Genteng & 12.477 .198 & 6.082 .965 & $49 \%$ & 8.939 .860 & $-32 \%$ \\
\hline 4 & KPP Pratama Surabaya Gubeng & 18.371 .123 & 4.917 .296 & $27 \%$ & 13.056 .480 & $-62 \%$ \\
\hline 5 & KPP Pratama Surabaya Karangpilang & 33.576 .43 & 11.449 .044 & $34 \%$ & 10.856 .188 & $5 \%$ \\
\hline 6 & KPP Pratama Surabaya Krembangan & 18.740 .974 & 5.868 .419 & $31 \%$ & 12.440 .418 & $-53 \%$ \\
\hline 7 & KPP Pratama Surabaya Mulyorejo & 11.156 .658 & 9.886 .877 & $89 \%$ & 10.816 .629 & $-9 \%$ \\
\hline 8 & KPP Pratama Surabaya Pabean Cantikan & 23.252 .574 & 9.123 .839 & $39 \%$ & 14.789 .893 & $-38 \%$ \\
\hline 9 & KPP Pratama Surabaya Rungkut & 48.391 .993 & 21.483 .136 & $44 \%$ & 33.258 .154 & $-35 \%$ \\
\hline 10 & KPP Pratama Surabaya Sawahan & 27.293 .589 & 15.960 .738 & $58 \%$ & 7.352 .281 & $117 \%$ \\
\hline 11 & KPP Pratama Surabaya Sukomanunggal & 141.781 .312 & 3.858 .579 & $3 \%$ & 25.399 .029 & $-85 \%$ \\
\hline 12 & KPP Pratama Surabaya Tegalsari & 13.109 .194 & 27.478 .943 & $210 \%$ & 42.009 .436 & $-35 \%$ \\
\hline 13 & KPP Pratama Surabaya Wonocolo & 81.599 .707 & 15.177 .060 & $19 \%$ & 19.062 .668 & $-20 \%$ \\
\hline
\end{tabular}


Berdasarkan hasil kuesioner, efektivitas CRM sebagai DSS berada dalam kategori baik dengan nilai 0,77 . Namun pada kenyataannya masih terdapat beberapa masalah yang membuat CRM belum berjalan secara efektif sebagai DSS. Data dalam CRM yang sejauh ini dimanfaatkan hanya Daftar Prioritas Pencairan. Peran Daftar Prioritas Pencairan tersebut pun hanya berupa data tambahan atau trigger, bukan DSS otomatis sebagaimana yang diharapkan saat risk engine tersebut dikembangkan oleh Direktorat Data dan Informasi Perpajakan. Masalah utama yang menghambat efektivitas CRM sebagai DSS adalah pemutakhiran data yang lambat. Apabila kelemahan tersebut diperbaiki, CRM akan mampu menyediakan profil risiko yang senantiasa akurat dan relevan dengan kondisi WP yang sesungguhnya. Dengan tersedianya profil risiko yang akurat, pengambilan keputusan dalam rangka penyusunan DPTPP akan berjalan dengan baik dan pada gilirannya membantu meningkatkan pencairan piutang pajak.

\subsubsection{Aspek Efisiensi}

Evaluasi atas efisiensi CRM sebagai DSS dilakukan untuk mengetahui apakah Juru Sita Pajak menggunakan waktu yang lebih singkat untuk menentukan prioritas tindakan penagihan dengan adanya CRM. Berdasarkan hasil evaluasi dengan teknik kuesioner, efisiensi dari CRM sebagai DSS berada pada level baik dengan nilai 0,75. Namun setelah digali melalui wawancara dan observasi, CRM belum dapat dikatakan efisien sebagai sebuah DSS. Sebab pemutakhiran data yang dilakukan paling cepat setiap tiga bulan. Hal tersebut membuat keandalan dan akurasi data yang tersedia tidak memadai sehingga data CRM tidak bisa secara langsung digunakan sebagai DSS yang otomatis. Akibatnya, sebelum memanfaatkan data CRM, Juru Sita Pajak harus terlebih dahulu melakukan validasi data untuk memastikan eksistensi dan jumlah tunggakan pajak, tindakan penagihan terakhir yang sudah dilakukan, bahkan kesesuaian antara profil risiko WP menurut CRM dan kondisi WP yang sesungguhnya.

DSS yang baik seharusnya dapat menghemat waktu penggunanya dalam mengambil keputusan. Namun dalam hal ini, karena relevansi data yang tidak selalu dapat diandalkan, Juru Sita Pajak masih harus melakukan penetapan DPTPP dengan langkah manual sebagaimana diatur dalam SE-29/PJ/2012 tentang Kebijakan Penagihan Pajak. Kalau pun Juru Sita Pajak memanfaatkan data dari CRM, proses penetapan DPTPP justru menjadi lebih panjang karena perlu dilakukan prosedur verifikasi terlebih dahulu atas data tersebut. Selain itu, data dari CRM sering kali tidak dapat diekspor sehingga Juru Sita perlu melakukan salin-tempel data secara manual dan prosedur tersebut cukup memakan waktu. Maka dapat disimpulkan bahwa CRM belum menjadi DSS yang efisien untuk kegiatan penagihan.

\subsubsection{Aspek Akurasi}

Evaluasi akurasi CRM sebagai DSS bertujuan untuk mengetahui apakah CRM menyediakan informasi yang cukup untuk membuat prioritas tindakan penagihan. Dalam hal ini, informasi profil risiko yang disajikan CRM harus sesuai kondisi Wajib Pajak yang sesungguhnya. Maka, data yang disediakan CRM baik yang terkait dengan sumbu $Y$ yaitu jumlah tunggakan pajak maupun yang terkait dengan sumbu $X$ yaitu kecenderungan membayar, harus akurat dan tepat.

Berdasarkan hasil evaluasi kuesioner, aspek akurasi berada pada level baik dengan skor usability 0,71 . Namun berdasarkan wawancara dan observasi, pada kenyataannya akurasi dari CRM Fungsi Penagihan masih minim. Pemutakhiran data yang dilakukan paling cepat setiap tiga bulan sekali tidak memadai untuk DSS yang terkait dengan penagihan pajak. Sebab data penagihan pajak utamanya berkaitan dengan ketetapan pajak yang statusnya selalu berubah-ubah. Kegagalan CRM mengimbangi dinamika dari ketetapan pajak adalah hal yang fatal. Sebab, nilai ketetapan pajak menempati sumbu $Y$ dari peta risiko yang berarti informasi tersebut merupakan parameter penting dalam penentuan skor risiko. Jika data ketetapan pajak yang disajikan tidak mutakhir, penilaian risiko akan menjadi tidak tepat. Akibatnya, Wajib Pajak akan ditempatkan di kuadran yang tidak mencerminkan kondisinya yang sesungguhnya. Hal ini menjelaskan data-data anomali yang kerap ditemukan di kuadran dalam peta risiko. Misalnya, Wajib Pajak yang ditempatkan di kuadran X3Y3 padahal tunggakan tersebut sudah lunas atau bahkan sudah daluwarsa penagihan.

Selain itu, risk engine ini juga harus memperbaiki akurasi dalam menyediakan data terkait kemampuan WP dalam melunasi utang pajaknya. Data pemicu yang dijadikan pertimbangan untuk menentukan kemampuan membayar sebaiknya tidak diambil dari data historis yang terlalu lampau. Misalnya, di salah satu KPP, terdapat Wajib Pajak yang memiliki nilai risiko tertinggi dalam kuadran X3Y3. Idealnya meskipun nilai tunggakan pajaknya tinggi, WP tersebut seharusnya tetap mampu melunasi tunggakannya karena memiliki kemampuan membayar yang tinggi pula. Namun setelah diperiksa kembali, aset yang dimiliki WP tersebut tidak cukup untuk melunasi tunggakannya. Satu-satunya data yang tampaknya memicu riskscoring tersebut adalah pembayaran pajak yang cukup signifikan yang berupa data setoran PPN lima tahun yang lalu. Sama halnya dengan data ketetapan pajak, apabila informasi kemampuan membayar WP tidak mutakhir, penilaian risiko akan menjadi tidak tepat. Akibatnya, peta risiko yang dihasilkan akan menyesatkan pengguna.

Dari penjelasan di atas dapat diketahui bahwa akurasi dari CRM sebagai DSS masih memerlukan perbaikan yang masif. Dengan akurasi data yang lebih tepat, peta risiko yang dihasilkan akan mencerminkan kondisi WP yang sesungguhnya. Hal ini juga akan 
berdampak positif pada aspek usability yang lain, yaitu efektivitas dan efisiensi CRM Fungsi Penagihan.

\subsubsection{Aspek Understandability}

Evaluasi aspek understandability CRM sebagai DSS bertujuan untuk mengetahui apakah Juru Sita Pajak selaku pengguna utama dari CRM mampu memahami istilah, alur, serta fungsi dari interface atau tampilan aplikasi CRM. Berdasarkan kuesioner usability, CRM telah memiliki tingkat understandability yang baik dengan skor 0,80. Secara umum hal ini sesuai dengan kondisi yang ditemukan di lapangan. Dari hasil observasi, Juru Sita Pajak tampak memahami alur penggunaan data CRM dan fungsinya. Selain itu, interface dari aplikasi CRM sendiri mudah dipahami dan cukup sederhana. Hal pertama yang ditampilkan oleh aplikasi CRM adalah peta risiko. Masing-masing kuadran dalam peta tersebut kemudian dapat diklik untuk mengakses data yang lebih rinci yang memuat identitas WP, informasi risiko penagihan, jumlah tunggakan, dan tindakan penagihan terakhir yang dilakukan.

Satu-satunya masalah yang ditemukan di lapangan adalah masih terdapat dua informan yang memiliki interpretasi yang keliru atas pemetaan risiko dalam CRM. Kuadran berwarna merah yang seharusnya diprioritaskan dalam tindakan penagihan justru diabaikan karena dianggap berisi WP yang sudah tidak memiliki kemampuan membayar. Sebaliknya, kuadran dengan warna hijau dianggap berisi WP yang memiliki likuiditas yang tinggi sehingga harus diprioritaskan untuk ditindaklanjuti. Hal tersebut sebenarnya juga disebabkan oleh tidak akuratnya data dalam beberapa kasus, terutama terkait ability to pay dari WP sehingga misinterpretasi tersebut timbul. Namun sebagian besar informan telah memiliki interpretasi yang benar atas peta risiko dan memahami alur serta fungsi dari CRM Fungsi Penagihan sehingga dapat diambil simpulan bahwa dari sebagai sebuah DSS, CRM Fungsi Penagihan memiliki tingkat understandability yang baik.

\subsubsection{Aspek Kemudahan Operasi (Operability)}

Evaluasi atas operability dari CRM sebagai DSS dilakukan untuk mengetahui apakah Juru Sita Pajak mampu mengoperasikan aplikasi CRM sesuai fungsinya. Selain itu, evaluasi ini juga bertujuan untuk mengetahui apakah CRM dapat digunakan kapan saja sesuai kebutuhan Juru Sita Pajak. Berdasarkan kuesioner usability, CRM telah berada pada level yang sangat baik dari segi operability dengan skor usability sebesar 0,82. Berdasarkan observasi yang dilakukan, skor tersebut telah mencerminkan kondisi yang sesungguhnya. Juru Sita dari berbagai latar belakang pendidikan serta demografi yang berbeda tidak mengalami kesulitan yang berarti dalam mengoperasikan aplikasi CRM. Namun ada kalanya rincian data setiap kuadran tidak dapat diekspor ke dalam format Microsoft Excel sehingga Juru Sita perlu menyalin data yang ada laman per laman. Jika permasalahan tersebut sudah diperbaiki, tingkat operability dari CRM sebagai DSS akan sempurna.

\subsubsection{Aspek Kemudahan untuk Dipelajar (Learnability)}

Evaluasi atas learnability dari CRM sebagai DSS dilakukan untuk mengetahui apakah Juru Sita Pajak mampu mempelajari cara menggunakan CRM dengan baik dan benar. Selain itu perlu didalami pula apakah istilah-istilah dalam aplikasi CRM mudah diingat oleh Juru Sita Pajak. Menurut hasil kuesioner usability, CRM telah memiliki learnability yang baik dengan skor 0,79 yang berarti CRM mudah dipelajari. Hal ini telah sesuai dengan kondisi di lapangan. Bentuk aplikasi CRM sangat sederhana dengan command atau perintah yang mudah diingat oleh Juru Sita. Hal ini membuat CRM mudah diterima dan digunakan sebagai DSS.

\section{KESIMPULAN DAN SARAN}

CRM Fungsi Penagihan dikembangkan untuk membantu penentuan prioritas tindakan dalam rangka menghasilkan penagihan yang lebih berkualitas. Tindakan penagihan yang berkualitas diharapkan dapat mengoptimalkan pencairan piutang pajak. CRM Fungsi Penagihan adalah risk engine yang memetakan risiko kepatuhan Wajib Pajak dari sisi penagihan dengan mempertimbangkan dampak fiskal dan kemampuan membayar. Dengan pemetaan risiko tersebut, CRM diharapkan mampu mengubah penetapan DPTPP yang semula harus dilakukan secara manual berdasarkan SE-29/PJ/2012 tentang Kebijakan Penagihan Pajak menjadi proses yang otomatis. Namun, karena pemutakhiran data yang lambat, gangguan akses data, dan perbedaan interpretasi peta risiko, data CRM Fungsi Penagihan belum dapat dijadikan DSS utama dalam penetapan DPTPP dan hanya berperan sebagai trigger atau data tambahan.

Hasil evaluasi lapangan menunjukkan bahwa efektivitas, efisiensi, dan akurasi dari CRM sebagai DSS belum memadai dan masih memerlukan perbaikan. Masalah utama yang berdampak negatif pada ketiga aspek penilaian tersebut adalah pemutakhiran data yang sangat lambat yang tidak mampu mengimbangi dinamika data penagihan pajak. Untuk meningkatkan efektivitas dari CRM Fungsi Penagihan, profil risiko yang disajikan harus mutakhir dan didukung dengan trigger data yang berkualitas, misalnya informasi rekening Wajib Pajak antarnegara yang bersumber dari Automatic Exchange of Information. Untuk meningkatkan aspek efisiensi, CRM Fungsi Penagihan harus menampilkan profil risiko yang andal sehingga tahap validasi ulang data CRM tidak perlu dilakukan oleh Juru Sita Pajak dan data CRM dapat langsung digunakan sebagai prioritas tindakan penagihan. Kemudian, untuk meningkatkan akurasi, pemutakhiran data di CRM perlu dilakukan paling tidak setiap dua minggu agar data masih relevan dengan kondisi utang pajak dan Wajib Pajak yang sesungguhnya. Sementara itu dari segi understandability, operability, dan learnability, CRM Fungsi Penagihan sudah mencapai level yang baik sebagai DSS. 
Penelitian ini mengonfirmasi pendapat Shafinah (2010) bahwa evaluasi kegunaan DSS dengan teknik kuesioner sebaiknya didukung dengan wawancara dan observasi yang dapat memberikan verifikasi dan validasi tingkat keberhasilan DSS secara lebih terperinci.

Direktorat Data dan Informasi Perpajakan perlu mengupayakan agar pemutakhiran data dalam CRM dilakukan dengan frekuensi yang lebih sering untuk mengikuti dinamika ketetapan pajak dan perkembangan kondisi Wajib Pajak. Untuk itu Direktorat Data dan Informasi Perpajakan perlu berkomunikasi dengan Direktorat Pemeriksaan dan Penagihan maupun kantor wilayah DJP agar dapat memahami sistem informasi seperti apa yang mampu mengakomodasi kebutuhan Juru Sita Pajak. Selain itu, Direktorat Data dan Informasi Perpajakan perlu melakukan monitoring dan evaluasi khusus terkait CRM yang memungkinkan pemberian saran dan masukan dari KPP untuk meningkatkan keberhasilan CRM Fungsi Penagihan. Direktorat Data dan Informasi Perpajakan juga perlu menunjuk narahubung khusus terkait CRM Fungsi Penagihan yang dapat dihubungi oleh KPP agar keluhan atau kendala terkait CRM dapat segera diketahui dan ditindaklanjuti secara responsif. Bimbingan teknis juga perlu lebih digalakkan oleh kantor wilayah DJP kepada KPP yang berada dalam naungannya untuk meningkatkan pemahaman Kepala Seksi P3 dan Juru Sita Pajak tentang CRM Fungsi Penagihan.

\section{IMPLIKASI DAN KETERBATASAN}

Sampai dengan berakhirnya waktu penelitian yang diberikan, penulis belum memperoleh izin riset dari Direktorat Data dan Informasi Perpajakan maupun Direktorat Pemeriksaan dan Penagihan yang diharapkan dapat menyempurnakan triangulasi informasi terkait implementasi dan keterbatasan dari CRM Fungsi Penagihan. Penelitian selanjutnya diharapkan dapat memperdalam dan menguatkan triangulasi dengan mengumpulkan data primer dari Direktorat Data dan Informasi Perpajakan selaku unit yang bertanggung jawab atas pengembangan CRM atau unit lain yang berkaitan dengan fungsi CRM yang dibahas.

Selain itu, penelitian ini menggunakan pendekatan usability inquiry yang sifatnya masih subjektif untuk menilai implementasi CRM Fungsi Penagihan. Penelitian selanjutnya dapat menggunakan pendekatan lain seperti usability evaluation yang memungkinkan evaluator melakukan observasi secara langsung atas pemanfaatan aplikasi CRM Fungsi Penagihan oleh penggunanya untuk menilai tingkat kegunaannya.

Penelitian ini juga dilakukan pada saat terjadi perombakan struktur organisasi di KPP yang meleburkan Seksi Penagihan dan Seksi Pemeriksaan ke dalam Seksi Pemeriksaan, Penilaian, dan Penagihan (P3) sehingga informan di Kanwil DJP Jatim I dengan pengalaman yang cukup di bidang penagihan pajak berjumlah terbatas. Hal ini menyebabkan snowball sampling yang dilakukan tidak mencapai tingkat saturasi yang sempurna sebagaimana direncanakan di awal penelitian. Penelitian selanjutnya dapat dilakukan dengan objek penelitian yang menyediakan jumlah informan yang memadai.

\section{DAFTAR PUSTAKA (REFERENCES)}

Bahan Tayang Bimbingan Teknis CRM Fungsi Penagihan, Direktorat Data dan Informasi Perpajakan (2019).

Barrett AO, P. (2014). New development: Risk management-how to regain trust and confidence in government. Public Money \& Management, 34(6), 459-464. doi:10.1080/09540962.2014.962376

Carlsson-Wall, M., Kraus, K., Meidell, A., \& Tran, P. (2018). Managing risk in the public sector: The interaction between vernacular and formal risk management systems. Financial Accountability \& Management. doi:10.1111/faam.12179

Chooi, A. (2020). Improving Tax Compliance: Establishing a Risk Management Framework. The Governance Brief, vol. 39.

Chowdhury, A. \& Shil, N.C. (2019). Influence of New Public Management Philosophy on Risk Management, Fraud and Corruption Control and Internal Audit: Evidence from an Australian Public Sector Organization. Journal of Accounting and Management Information Systems, Faculty of Accounting and Management Information Systems, The Bucharest University of Economic Studies, vol. 18(4), pages 486-508, December. http://dx.doi.org/10.24818/jamis.2019.04002

Drucker, P. F. (1954). The practice of management. New York: Harper \& Row

European Commission. 2010. Compliance Risk Management Guide for Tax Administrations. Luxembourg: Office for Official Publications of the European Commission.

Highfield, R. (2013). Efficient Revenue Administration. Dalam Allen R., Hemming R., Potter B.H. (Penyunting) The International Handbook of Public Financial Management (pp. 453-479). Palgrave Macmillan, London. https://doi.org/10.1057/9781137315304

Kapuscinska, K., Matejun, M. (2014). Risk Management in Public Sector Organizations: A Case Study. International Journal of Business and Management Studies, 3(3), 129-143.

Kong, Y., Lartey, P. Y., Bah, F. B. M., \& Biswas, N. B. (2018). The Value of Public Sector Risk Management: An Empirical Assessment of Ghana. Administrative Sciences, 8(3), 40. doi:10.3390/admsci8030040

Leung, F., \& Isaacs, F. (2008). Risk management in public sector research: approach and lessons learned at a national research organization. R\&D Management, 38(5), 510-519. doi:10.1111/j.1467-9310.2008.00529.x

Organisation for Economic Co-operation and Development (OECD). (2004). Compliance Risk 
Management: Managing and Improving Tax Compliance. Paris: OECD Forum on Tax Administration. http://www.oecd.org/tax/ administration/33818656.pdf.

Palermo, T. (2014). Accountability and Expertise in Public Sector Risk Management: A Case Study. Financial Accountability \& Management, 30(3), 322-341. doi:10.1111/faam.12039

Parhizkar, T., Hogenboom, S., Vinnem, J. E., \& Utne, I. B. (2020). Data driven approach to risk management and decision support for dynamic positioning systems. Reliability Engineering \& System Safety, 201, 106964. doi:10.1016/j.ress.2020.106964

Peculea, A. D., \& Chitescu, R. I. (2015). The Role of Decision Support Systems (DSS) in the Optimization of Public Sector Management. Paper presented at FINIZ 2015 - Contemporary Financial Management. doi:10.15308/finiz2015-137-141

Peignot, J., Peneranda, A., \& Amabile, S. (2012). Strategic Decision Support Systems for Local Government: A Performance Management Issue? The Use of Information Systems on the Decision-making and Performance Management of Local Government. International Business Research, 6(2). doi:10.5539/ibr.v6n2p92

Pick, R. A., \& Weatherholt, N. (2013). A Review on Evaluation And Benefits Of Decision Support Systems. Review of Business Information Systems (RBIS), 17(1), 7-20. https://doi.org/10.19030/rbis.v17i1.7580
Simon, H. A. (1977), The New Science of Management Decision (3rd revised edition; first edition 1960). Prentice-Hall, Englewood Cliffs, NJ.

Shafinah, K., Selamat, M.H., Abdullah, R., Nik Muhamad, A.M., \& Awang Noor, A.G. (2010). System Evaluation for a Decision Support System. Information Technology Journal, 9: 889-898. 10.3923/itj.2010.889.898

Sugiyono. (2018). Metode Penelitian Kuantitatif, Kualitatif, dan Kombinasi (Mixed Method). Bandung: Alfabeta.

Surat Edaran Direktur Jenderal Pajak Nomor SE29/PJ/2012 tentang Kebijakan Penagihan Pajak.

Surat Edaran Direktur Jenderal Pajak Nomor SE24/PJ/2019 tentang Implementasi Compliance Risk Management dalam Kegiatan Ekstensifikasi, Pengawasan, Pemeriksaan, dan Penagihan di Direktorat Jenderal Pajak.

Vincent, J. (1996). Managing risk in public services. International Journal of Public Sector Management, 9(2), 57-64. doi:10.1108/09513559610119564

Vinnari, E., \& Skaerbaek, P. (2014). The uncertainties of risk management. Accounting, Auditing \& Accountability Journal, 27(3), 489-526. doi:10.1108/aaaj-09-2012-1106

Woods, M. (2009). A contingency theory perspective on the risk management control system within Birmingham City Council. Management Accounting Research, 20(1), 69-81. doi:10.1016/j.mar.2008.10.003 